\title{
Can the grey literature help us understand the decline and extinction of the Near Threatened Eurasian otter Lutra lutra in Latium, central Italy?
}

\author{
Corrado Battisti, Giovanni Amori, Francesco M. Angelici \\ LUCA LUISELLI and MARZIOZAPPAROLI
}

\begin{abstract}
To trace the local extinction of the Eurasian otter Lutra lutra in Latium, central Italy, and examine the causes of the species' disappearance, we reviewed and classified information from both the scientific and grey literature according to the reliability and geographical accuracy of the records. The temporal and spatial patterns of 160 records from 23 geographical subunits from 1832 to 2006 suggest that the species collapsed between 1960 and 1975; two different extinction patterns were revealed by a set of multivariate analyses. In northern Latium the species collapsed because of several independent local threats. In central and southern Latium the species collapsed because of catastrophic habitat alteration (land reclamation during the 1930s) that negatively affected the source population. After this event the species went extinct in hilly and mountainous areas, where several population sinks occurred. We presume that this latter process drove the remnant otter subpopulations to extinction in central Italy, emphasizing the role of an extinction vortex in causing the collapse of this metapopulation rather than the classical threats recognized for this species. The value of the grey literature for a posteriori historical analysis of local extinction dynamics is highlighted by this research.
\end{abstract}

Keywords Central Italy, Eurasian otter, extinction vortex, grey literature, Lutra lutra, scientific literature

This paper contains supplementary material that can be found online at http://journals.cambridge.org

\section{Introduction}

The term grey literature defines any source of written

Corrado Battisti Ufficio Conservazione Natura, Servizio Ambiente, Provincia di Roma, Rome, Italy

Giovanni Amori (Corresponding author) Consiglio Nazionale delle Ricerche, Istituto per lo Studio degli Ecosistemi, Istituto di Anatomia Comparata, Università degli Studi di Roma "Sapienza", via A. Borelli 50, 00161 Roma, Italy. E-mail giovanni.amori@uniroma1.it

Francesco M. Angelici and Luca Luiselli Environmental Studies Centre Demetra s.r.l., Rome, Italy

Marzio Zapparoli Dipartimento di Protezione delle Piante, Università degli Studi della Tuscia, Viterbo, Italy

Received 3 December 2009. Revision requested 9 March 2010.

Accepted 20 March 2010. commercially or is not generally accessible (Debachere, 1995). In conservation biology, ecology and zoology this term generally identifies technical manuscripts that have not been peer reviewed, including reports from governmental and non-governmental agencies and local publications. In general, peer-reviewed research journals do not accept grey literature sources as valid background information. However, there are some cases in which most, if not all, the information on a sensitive problem (for instance, the progressive extinction of threatened species) is available only in the grey literature. It has been demonstrated in the medical sciences that the exclusion of this literature from meta-analyses can lead to biased results (McAuley et al., 2009). Here, therefore, we use a combination of peer-reviewed and carefully selected grey literature to analyse the extinction of the Eurasian otter Lutra lutra in central Italy.

The Eurasian otter is categorized as Near Threatened on the IUCN Red List (Ruiz-Olmo et al., 2008), listed in Appendix II of the Berne Convention, on Annexe II of EU Directive 92/43, and has been protected since 1977 in Italy (Prigioni, 2003). Otter populations have declined severely over the last 50 years in Central Europe (Hájková et al., 2007), including Italy, but viable populations have survived in Portugal, Greece and south-east Europe (MacDonald \& Mason, 1983, 1994; Conroy \& Chanin, 2002). Although some populations are still declining (see Prigioni et al., 2005, for a review), otters are recovering in several parts of western Europe, including Italy, probably as a consequence of legal protection and the banning of pesticides in the $1980 \mathrm{~s}$.

Several factors, either independent or interrelated, may be driving the decline of otters in some areas, including human persecution, habitat fragmentation and alteration (e.g. pollution, reduction in food supply, availability of suitable water bodies, and road traffic casualties; Mason, 1995; Reuther, 1995; Ruiz-Olmo et al., 2002; for Italy: Fumagalli \& Prigioni, 1993; Bulgarini et al., 1998; Reggiani \& Loy, 2006).

The remnant otter populations in Italy are confined to the south (Loy \& Racana, 1986; Loy et al., 2002; Marcelli et al., 2007). Isolated subpopulations were recorded in central Italy until the 1990s (Boitani et al., 2003; Prigioni et al., 2005, 2006, 2007; Giovacchini \& Stefanini, 2008; Marcelli \& Fusillo, 2009). In Latium in central Italy the otter declined during the second half of the 2oth century and is now considered locally extinct (Boitani, 2008). The 
extinction of otters in this region is documented by a large body of mainly grey literature. We reviewed all the available information in both the primary and grey literature on the occurrence of the Eurasian otter in Latium and used this to trace the progressive disappearance of the species and develop a model of its local extinction.

\section{Study area}

The study area includes the c. $17,000 \mathrm{~km}^{2}$ political territory of Latium, with c. 5,100,000 people and a mean density of 297 inhabitants per $\mathrm{km}^{2}$ (Regione Lazio, 2000, 2004), and some adjacent areas of southern Tuscany and southern Umbria. We included these adjacent territories because some of the rivers of Latium lie along their borders. The study area extends from the Apennines to the Tyrrhenian Sea and is characterized by a high level of habitat diversity, with mountains (26\%), hills (54\%), and alluvial lowlands (20\%).

\section{Methods}

We collected and critically reviewed all the available data, both published and unpublished, on the presence and conservation status of otters in Latium from 1832. Records were obtained from: (1) historical literature (textbooks and articles in scientific periodicals published from 1816 to the 1950s); (2) modern scientific literature (textbooks and articles published in peer-reviewed journals since 1960); (3) grey literature (i.e. not peer-reviewed literature, mostly published since 1970, including technical reports and popular articles); (4) unpublished museum data; (5) an official mammal database (Provincia di Roma mammals database: Amori et al., 2009); (6) a selection of personal communications from experienced local zoologists and naturalists.

Bibliographic data may differ in reliability and accuracy in regard to both correct identification of species in the field and preciseness of the geographic coordinates of a record. Records were therefore classified according to (1) level of reliability (high, $\mathrm{H}_{1}$, if from a reliable source or low, $\mathrm{L}_{1}$, if from a potentially unreliable source), and (2) level of geographical accuracy (high, $\mathrm{H}_{2}$, if the site is detailed and unambiguous, or low, L2, if the site is vague and refers to a large area, such as a river basin or mountain range or part thereof).

Records were grouped into 23 subunits by local river basins and streams. To make the general discussion easier to follow we grouped some subunits into mountain or hill systems. The records from each subunit were ordered chronologically (Appendix). Where available in the original source we also included pertinent annotations for each record. For example, we included annotations of the conservation status of the local population at the time (such as extinct, almost extinct, abundant, presence not confirmed), the type of evidence for the species' presence (direct observations, sighting of tracks), and whether evidence of the presence of the species was obtained from interviews (Cagnolaro et al., 1975; Pavan \& Mazzoldi, 1983). Using only the highly reliable records $\left(\mathrm{H}_{1}\right)$ similarities in temporal disappearance of the otter among geographical subunits were clustered using multivariate factor analysis, with Ward's method and Euclidean distances as similarity measures. We used STATISTICA v. 6.o (Statsoft, Inc., Tulsa, USA) for statistical analyses.

\section{Results}

In total we located 160 records $\left(\mathrm{H}_{1}=82, \mathrm{H}_{2}=47, \mathrm{~L}_{1}=5\right.$, $\mathrm{L}_{2}=26$ ) for the 23 subunits (Appendix) from 46 sources: 38 original bibliographic sources (including grey literature and technical papers) and eight unpublished personal communications. The earliest record came from the second decade of the 19th century (Giustiniani, 1816), and the latest from 2003 (Dream Italia et al., 2004). About $26 \%$ of the 160 records came from the coastal and sub-coastal subunits (i.e. Tarquinia, Agro Romano and Pontina plain), probably reflecting a higher sampling effort in these subunits. Records of otters progressively increased during 19561975, decreased from 1976-1980 to the present, and no subunits were occupied in 2006-2010 (Fig. 1). This pattern is, however, biased because of the limited records available prior to the 1970 .

A factor analysis clustering the subunits in terms of the temporal disappearance of otters resulted in three clusters (Fig. 2). We did not examine cluster III further because it contained few records. The approximate geographical locations of the three clusters in Latium is shown in Fig. 3. Based on the percentage of subunits occupied by otters by year it appeared that the decline of the otter began in 1960 and became catastrophic by 1975 (Fig. 4). The earliest extinction occurred in the Lepini mountains, in southern Latium. Further extinctions occurred, more or less contemporaneously, in other mountain areas in southern Latium (Simbruini, Ausoni-Aurunci, Ernici, River Melfa and Prenestini). Further extinctions then occurred in both northern (Volsini-Bolsena, Cimini Vicani, Mount Rufeno, River Paglia, River Tiber, Lake Bracciamo) and southern Latium, including mountains (Sabini, Farfa and Reatini) and lowland areas (Agro Romano, Pontina plain and Circeo).

\section{Discussion}

Our review shows that the Eurasian otter was widespread across Latium during the early years of the 19th century (Fig. 1). Considering the presumed low field effort by biologists at that time it is likely that the species is underrepresented in terms of number of recorded occurrences 


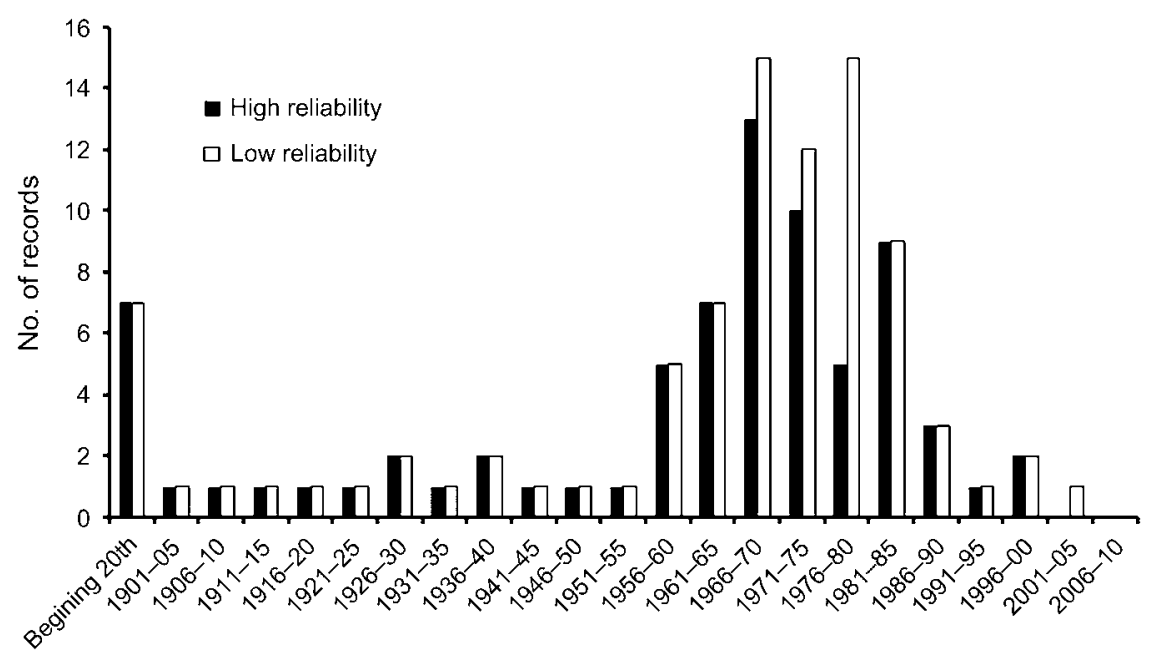

Fig. 1 Temporal distribution of the 160 records of the Eurasian otter Lutra lutra obtained from both the grey and scientific literature, for all subunits combined.

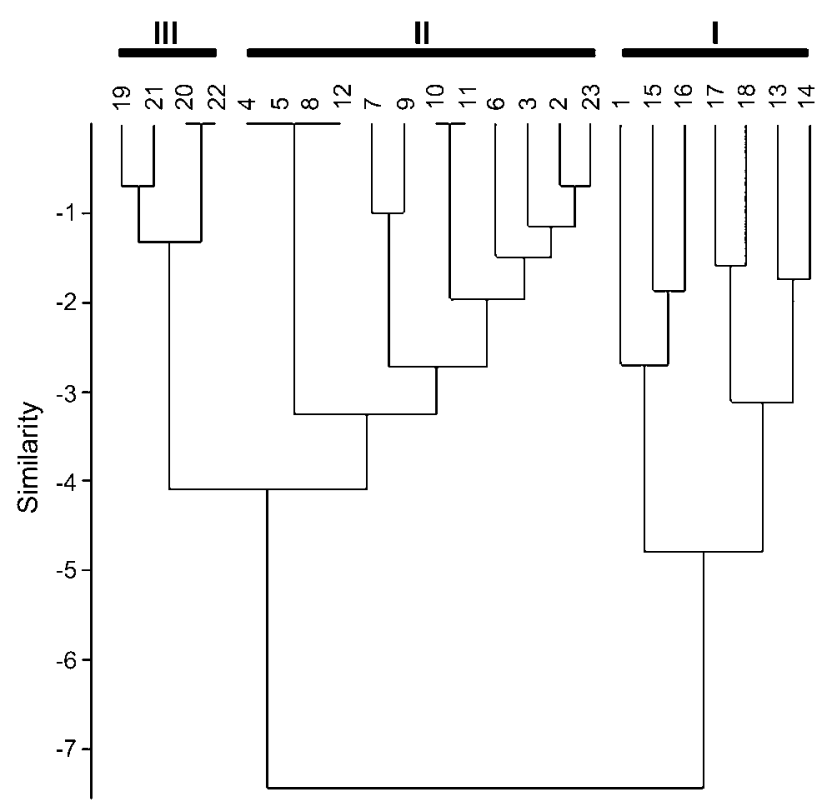

FIG. 2 Dendrogram from multivariate factor analysis of the 160 records of the Eurasian otter, showing the similarities among the 23 subunits (numbered at top) of Latium with respect to the timing of the disappearance of the otter, and the three geographical clusters (I, II, III). 1, Flora and Paglia rivers; 2, Flora, Tafone and Arrone river basins; 3, Saline di Tarquinia; 4, Vulsini mountains, Lake Bolsena and River Marta basin; 5, Cimini and Vicani mountains; 6, Monte Rufeno and River Paglia; 7, River Paglia; 8, River Tiber in Viterbo province; 9, Treia and River Tiber; 10, Mignone River basin, Tolfa mountains and northern coastal areas; 11, Lake Bracciano; 12, Rome, Agro Romano and littoral areas (including Castelporziano); 13, Simbruini Mountains and the high valley of River Aniene; 14, Lucretili mountains and low Sabina region; 15, Pontina plain, Circeo, and southern Latium coastal regions; 16, Ausoni-Aurunci mountains; 17, Ernici mountains; 18, River Melfa; 19, Lepini mountains; 20, Prenestini mountains, River Sacco, and Fiumicino and Aniene rivers; 21, Sabini mountains and River Farfa; 22, Reatini mountains; 23, River Tiber (Rome province). and was probably then a common species. Since vast lowland areas of Latium were a floodplain (Pennacchi, 2003), and presumably suitable for otters, it is likely that these extended marshlands were a source population for the species (Fig. 3).

From 1900 to the end of the 1950s information on the species was extremely scarce (Fig. 1), again most likely a result of the scarcity of field research. There was an increase in records from the 1960 s to the 1980s, probably because of an increase in both research effort and the amount of grey literature available. Based only on the highly reliable records the otter began to disappear between 1960 and 1975 in at least two geographical areas; i.e. in northern Latium and the River Tiber plain and its main tributaries. Clusters I and II were probably separate subpopulations.

Cluster I, the subpopulation of northern Latium, was probably separated from conspecifics by the River Tiber and its tributaries because there is a gap in riverine connections between the river basins in northern Latium and the River Tiber (Boni et al., 1988; Ventriglia, 1990). Hence, the otter subpopulation of northern Latium was probably not connected with the supposed source population in the lowland wetlands of central and southern Latium. This northern Latium subpopulation was probably subjected to a plethora of local threats (e.g. site-specific habitat alteration, human persecution). Extinctions were therefore localized and the few remnant populations linked to the better preserved areas survived until recently (e.g. in the River Mignone). These small remnant populations were the last to go extinct in Latium.

The otters of cluster II, the subpopulation in the River Tiber basin and southern Latium, were once widespread and probably locally abundant throughout the lowlands of Latium. These lowland wet areas were destroyed, however, during the 1930 s by Benito Mussolini's land reclamation programme, which started in 1924 (Bonifica Pontina; Pennacchi, 2003). It is likely that this land reclamation 


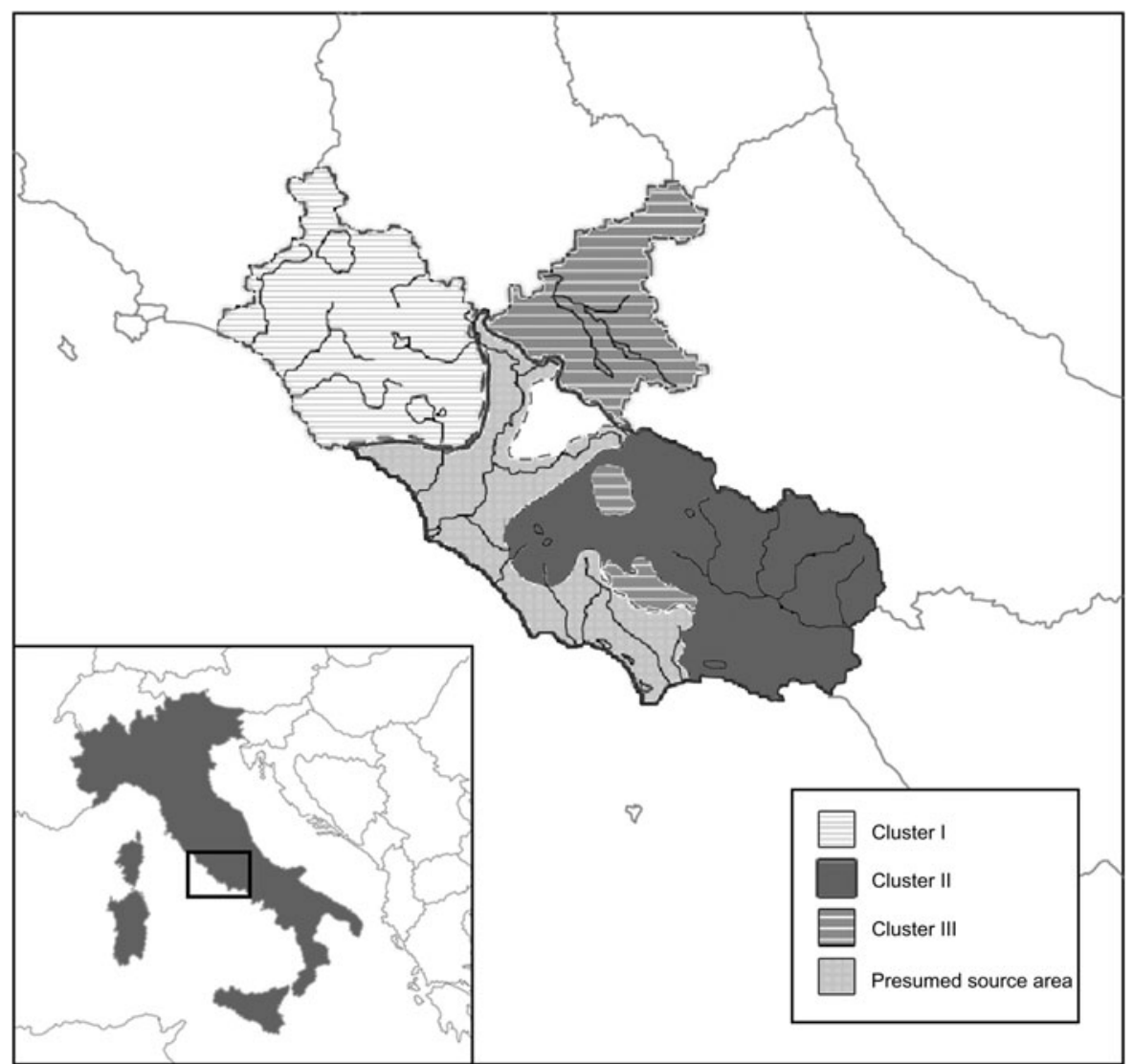

FIG. 3 The study area, showing the three geographical clusters from the multivariate factor analysis (Fig. 2). The presumed source area is part of clusters I and II. The rectangle on the inset indicates the location of the main map in central Italy.

programme fragmented the otter source population, with the ultimate fragments occurring only in a few secondary river basins; i.e. some tributaries of the River Tiber and the River Aniene, and the mountainous and hilly streams of Lepini, Prenestini, Lucretili, Simbruini and Ernici. Following fragmentation and isolation these subpopulations presumably became demographic sinks, with low density and a negative ratio between birth and death (Hanski, 1994, 1998). The exchange of individuals between the source population and the sink subpopulations decreased and eventually halted within a few decades, apparently without specific threats affecting them. This rapid extinction also

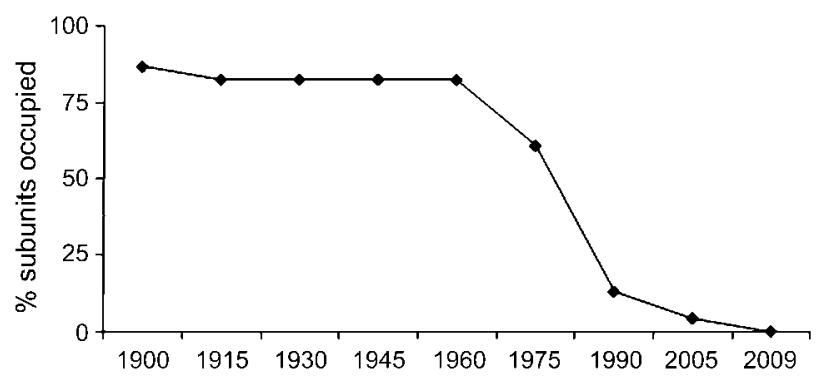

FIG. 4 Temporal decline of the European otter in Latium in terms of percentage of occupied subunits in the study area. occurred because otter density is usually low, with individuals requiring large areas (c. $15-50 \mathrm{~km}^{2}$, with 1 individual every 18-39 km along streams and rivers; Green et al., 1984). It is possible that a stochastic extinction vortex (Gilpin \& Soulé, 1986; PACLO, 2006) was established within the sink subpopulations as a consequence of the rapid collapse of the source population. In the second half of the 2oth century local extinctions were possibly induced more by stochastic factors (demographic, environmental and genetic) than by deterministic local anthropogenic threats (direct persecution, pollution, habitat destruction and transformation; Boitani et al., 2003). A source-sink scenario has been suggested as a cause of the local extinction of the Eurasian otter in Northern Europe, where formerly closed populations have been reduced in number and split into isolated, inviable subpopulations (Reuther, 1995).

Threats identified as a cause of local extinction of otter populations in many areas of Europe (IUCN, 2002) were probably irrelevant in Latium. For example, in northern Latium (Tolfa, Cimini, Vulsini and Vicani) freshwater habitat quality is high (Mancini \& Arcà, 2000) and rivers (e.g. Mignone, Marta) and lakes (e.g. Bolsena, Vico) have rich fish assemblages (Tancioni \& Cataudella, 2009). These areas have a low level of direct or indirect human 
disturbance (Contoli et al., 1980; Olmi \& Zapparoli, 1992). However, these rivers are relatively short (e.g. River Mignone: $62 \mathrm{~km}$; River Marta: $50 \mathrm{~km}$ ), and consequently a single river would have potentially hosted only a few individual otters (c. 1-10).

The Eurasian otter in Latium apparently went extinct within 2-3 decades. The temporal discrepancy between the catastrophic Bonifica Pontina of 1930s and the apparent decline of the otter from 1960 onwards was probably due to a lag effect (Tilman et al., 1994). The lifespan of a Eurasian otter is 15-17 years (Acharjyo \& Mishra, 1983; Chanin, 1985; Kruuk, 2006), which is consistent with such a time lag.

The grey literature proved to be a valuable source of information for analyses of the local extinction of the Eurasian otter in Latium. A large number of bibliographical sources exist from which information can be obtained (e.g. hunting diaries), especially for large charismatic or game species. With such sources it is possible to reconstruct the decline or extinction of a species, at least in European contexts where these types of data are available and span a number of decades.

\section{Acknowledgements}

We thank A. Baragliu, C. Belfiore, G. Biddittu, M.A. Bologna, G.M. Carpaneto, P. Carradori, G. Catullo, S. Celletti, L. Corsetti, M. Cristaldi, D. D'Amelia, S. D'Antoni, R. Fochetti, F. Fraticelli, P. Genovesi, M. Ghigi, S. Gippoliti, I. Guj, C. Marangoni, A. Monaco, S. Muratore, L. Nieder, V. Orchi, R. Papi, E. Piattella, F. Pratesi, F. Petretti, P. Politi, S. Sarrocco, G. Reggiani, B. Renzi, F. Scarfò, C. Utzeri and A. Vigna Taglianti for their valuable help with information, references and suggestions, and R. Malavasi and G. Milana for drawing the figures, and A. Loy and an anonymous reviewer for helpful comments.

\section{References}

Acharjyo, L.N. \& Mishra, C.G. (1983) A note on the longevity of two specimens of Indian otters in captivity. Journal of the Bombay Natural History Society, 80, 636.

Amori, G., Battisti, C. \& De Felici, S. (2009) I mammiferi della Provincia di Roma. Dallo stato delle conoscenze alla gestione e conservazione delle specie. Provincia di Roma, Stilgrafica, Roma, Italy.

Angelici, F.M. (1989) I Mammiferi dei monti Cimini e Vicani: popolamento, confronto faunistico con altre aree del Lazio e considerazioni zoogeografiche. $\mathrm{PhD}$ thesis. Università degli studi la Sapienza di Roma, Rome, Italy.

ANGELICI, F.M. (2005) I Mammiferi. In I Monti della Tolfa, paesaggi, ambienti, tradizioni (ed. C. Forniz), pp. 105-117. Regione Lazio, Ass. alla Cultura, Pieraldo Editore, Rome, Italy.

Angelici, F.M. \& Riga, F. (2001) I mammiferi dei Monti Prenestini. In Aspetti naturalistici dei Monti Prenestini (ed. F.M. Angelici), pp. 181-199. Associazione naturalistica "Orchidea", Regione Lazio, Assessorato all'Ambiente, Rome, Italy.

A RCÀ, G. (1986) La Lontra nel bacino del Fiume Fiora. In La Lontra in Italia, censimento, distribuzione e problemi di conservazione di una specie minacciata (ed. F. Cassola), pp. 81-87. WWF, Serie Atti e Studi, 5, Rome, Italy.

ArCÀ, G. \& Prigioni, C. (1987) Food of the otter on the Fiora River (Central Italy). Acta Theriologica, 32, 134-140.

Biondi, M. (1985) Aspetti faunistici del Parco Nazionale del Circeo. I Quaderni del Parco, 6, 1-47.

Boit ani, L. (2008) Lutra lutra (Linnaeus, 1758)-Lontra. In Habitat e specie di interesse comunitario nel Lazio (eds E. Calvario, S. Sebasti, R. Copiz, F. Salomone, M. Brunelli, G. Tallone \& C. Blasi), pp. 382-383. Edizioni ARP, Agenzia Regionale Parchi, Rome, Italy.

Boitani, L., Lovari, S. \& Vigna Taglianti, A. (2003) Mammalia III. Carnivora, Artiodactyla. Fauna d'Italia. Calderini, Bologna, Italy.

Bona PARTE, C.L. (1832-1841) Iconografia della fauna italica per le quattro classi degli animali vertebrati. Tomo I: Mammiferi e Uccelli. Tipografia Salviucci, Roma, Italy. [reprint edited by Minelli, A. \& Vigna Taglianti, A. (eds) (2003) Ministero dell' Ambiente e della Tutela del Territorio, 3 vol.]

Boni, C., Bono, P. \& Capelli, G. (1988) Carta Idrogeologica del Territorio della Regione Lazio (Scala 1:250.00o). Assessorato Programmazione, Ufficio Parchi e Riserve Naturali della Regione Lazio. Dipartimento di Scienze della Terra, Università degli Studi la Sapienza di Roma, Rome, Italy.

Bulgarini, F., Calvario, E., Fraticelli, F., Petretti, F. \& Sarrocco, S. (1998) Lista rossa degli Animali d'Italia -Vertebrati. WWF Italia, Roma, Italy.

Cagnolaro, L., Rosso, D., Spagnesi, M. \& Venturi, B. (1975) Inchiesta sulla distribuzione della Lontra (Lutra lutra) in Italia e nei Cantoni Ticino e Grigioni (Svizzera) 1971-1973. Ricerche di Biologia della Selvaggina, 63, 1-120.

Calò, C.M. \& Verucci, P. (1993) I mammiferi selvatici della Provincia di Roma. Provincia di Roma, Assessorato Ambiente, WWF Delegazione Lazio, Rome, Italy.

Cammerini, G. (1986) La Lontra nella Provincia di Rieti. In $L a$ Lontra in Italia, censimento, distribuzione e problemi di conservazione di una specie minacciata (ed. F. Cassola), pp. 88-89. WWF, Serie Atti e Studi, Rome, Italy.

Canu, A. \& Penteriani, V. (1986) La lontra nel Lazio meridionale. In La Lontra in Italia, censimento, distribuzione e problemi di conservazione di una specie minacciata (ed. F. Cassola), pp. 92-94. WWF, Serie Atti e Studi, 5, Rome, Italy.

Cassola, F. (1976) Primi passi per la Lontra. Atti WWF Italia, 5, $19-21$.

CAssola, F. (ed.) (1986) La lontra in Italia, censimento, distribuzione e problemi di conservazione di una specie minacciata. WWF Serie Atti e Studi, 5, Rome, Italy.

Celletti, S. (1996) La Lontra (Lutra lutra). In Fauna vertebrata terrestre della Provincia di Viterbo (eds A. Meschini \& R. Papi), pp. 49-50. Amministrazione Provinciale di Viterbo, Assessorato all'Ambiente, Associazione GUFO e Associazione FAGUS, Viterbo, Italy.

Celletti, S. \& Papi, R. (2003) Fauna vertebrata terrestre della Provincia di Viterbo. In Relazione sullo Stato dell'Ambiente. Provincia di Viterbo (eds M. Ciambella, M. Buratto, E. Dello Vicario, A. Pozzi \& A. Riccardi), pp. 145-154. Assessorato Ambiente e Pianificazione territoriale, Viterbo, Italy.

Cenni, M. (1986) La Lontra in Toscana. In La Lontra in Italia, censimento, distribuzione e problemi di conservazione di una specie minacciata (ed. F. Cassola), pp. 63-64. WWF, Serie Atti e Studi, 5, Rome, Italy. 
Chanin, P. (1985) The Natural History of the Otters. Crom Helm, London, UK.

Conroy, J.W.H. \& Chanin, P.R.F. (2002) The status of Eurasian otter (Lutra lutra). IUCN Otter Specialist Group Bulletin, 19, 24-58.

Contoli, L. (1977) Mammiferi del Tolfetano-Cerite (Lazio). Quaderni dell' Accademia Nazionale dei Lincei, Roma, 127, 191-226.

Contoli, L., Lombardi, G. \& Spada, F. (1980) Piano per un Parco Naturale nel territorio di Al lumiere e Tolfa (Provincia di Roma). Provincia di Roma, Istituto Poligrafico e Zecca dello Stato, Rome, Italy.

Contoli, L. \& Spada, F. (1973) Sulle prospettive per la razionale gestione e tutela dell'ambiente naturale nel comprensorio Tolfetano-Cerite (Lazio). III Symposium on Nature Conservation, Bari, 2-6 May 1973, Bari, Italy.

Cooperativa, Lynx (1986) Indagine naturalistica nel comprensorio del Comune di Ischia di Castro (VT). Lynx Coop. srl., Rome, Italy.

Debachere, M.C. (1995) Problems in obtaining grey literature. IFLA Journal, 21, 94-98.

Dream Italia, Lynx Natura e Ambiente \& Temi Ambiente (2004) Piani di gestione e regolamentazione sostenibile dei SIC e ZPS assegnati alla Riserva Naturale Selva del Lamone. Unpublished. Farnese, Italy.

Forti, G. \& PAPI, R. (2004) Il territorio, la flora e la fauna. In Guida ai servizi delle aree naturali protette del Lazio, Riserva Naturale Monte Rufeno, pp. 7-24. Regione Lazio, Assessorato all'Ambiente, Rome, Italy.

Fumagalli, R. \& Prigioni, C. (1993) Evoluzione della distribuzione della Lontra (Lutra lutra) in Italia e possibilità di sopravvivenza dei nuclei residui. Supplementi Ricerche Biologia Selvaggina, 21, 197-207.

Ghigi, A. (1911) Ricerche faunistiche e sistematiche sui mammiferi d'Italia che formano oggetto di caccia. Natura, Milano, 2, 289-337.

Gilpin, M.E. \& Soulé, M.E. (1986) Minimum viable populations: processes of species extinction. In Conservation Biology (ed. M.E. Soulé), pp. 19-34. Sinauer Associates Inc., Sunderland, USA.

Giovacchini, P. \& S TEFANini, P. (2008) La protezione della natura in Toscana. Siti di Importanza Regionale e fauna Vertebrata nella provincia di Grosseto. Quaderno delle Aree Protette, 3, Grosseto, Italy.

Gippoliti, S. \& Amori, G. (2006) Historical data on non-volant mammals in Rome: what do they say about urban environment? Aldrovandia, 2, 69-72.

Giustiniani, L. (1816) Dizionario geografico ragionato del Regno di Napoli. I fiumi, i laghi, fonti, golfi, monti, promontori, vulcani, boschi del Regno di Napoli. Vol. XI, XII, XIII, Napoli (reprint, Forni Ed., Bologna, 1971). Società Reale, Naples, Italy.

Green, J., Green, R. \& Jefferies, D.J. (1984) A radio-tracking survey of otters Lutra lutra on a Perthshire river system. Lutra, 27, $85-145$.

Hájková, P., Pertoldi, C., Zemanová, B., Roche, K., Hájek, B., BRYjA, J. \& Zima, J. (2007) Genetic structure and evidence for recent population decline in Eurasian otter populations in the Czech and Slovak Republics: implications for conservation. Journal of Zoology, 272, 1-9.

HANSKI, I. (1994) A practical model of metapopulation dynamics. Journal of Animal Ecology, 63, 151-162.

Hanski, I. (1998) Metapopulation dynamics. Nature, 396, 41-49.

KRUUK, H. (2006) Otters: ecology, behaviour and conservation. Oxford University Press, Oxford, UK.

IUCN (2002) 2002 IUCN Red List of Threatened Animals. IUCN, Gland, Switzerland.

IUCN (2009) 2009 IUCN Red List of Threatened Animals. IUCN, Gland, Switzerland.
Loy, A. \& RACANA, A. (1986) La lontra in Basilicata. In La lontra in Italia, censimento, distribuzione e problemi di conservazione di una specie minacciata (ed. F. Cassola), pp. 110-113. WWF, Serie Atti e Studi, 5, Rome, Italy.

Loy, A., Bucci, L., Carranza, M.L., Di Martino, P., Di Marzio, P. \& Reggiani, G. (2002) Censimento della lontra (Lutra lutra, Carnivora, Mammalia) in Molise e validazione di modelli di idoneità ambientale attraverso applicazioni GIS. In Symposium on "I Sistemi di Informazione Geografica (GIS) nella gestione e lo sviluppo dell'ambiente e del territorio" (eds G. Pappone, E. Casciello, M. Cesarano \& G. Piacquadio). pp. 86-89. University of Isernia, Isernia, Italy.

Knotterus - Meyer, T. (1924) Nel Giardino Zoologico. Osservazioni e studi. Maglini e Strini, Roma, Italy.

LEPRI, G. (1911) Aggiunte alle ricerche faunistiche e sistematiche sui Mammiferi d'Italia che formano oggetto di caccia. Bollettino della Società Zoologica Italiana, 12, 241-250.

MacDonald, S.M. \& Mason, C.F. (1983) The otter in Southern Italy. Biological Conservation, 25, 95-101.

MacDonald, S.M. \& Mason, C.F. (1994) Status and Conservation Needs of the Otter (Lutra lutra) in the Western Palearctic. Council of Europe, Brussels, Belgium.

Mancini, L. \& ArCÀ, G. (eds) (200o) Carta della qualità biologica dei corsi d'acqua della Regione Lazio. Istituto Superiore di Sanità, Lab. di Igiene Ambientale-Regione Lazio Assessorato Ambiente, Dipartimento Ambiente e Protezione civile, Rome, Italy.

Mantero, F.M. (undated) Primi contributi alla conoscenza del territorio della Riserva Naturale Regionale Monterano. Quaderni della Riserva Naturale Regionale Monterano, 7, 1-322.

Marcelli, M. \& Fusillo, R. (2009) Assessing range re-expansion and recolonization of human-impacted landscapes by threatened species: a case study of the otter (Lutra lutra) in Italy. Biodiversity and Conservation, 18, 2941-2959.

Marcelli, M., Fusillo, R. \& Boitani, L. (2007) Distribuzione della Lontra (Lutra lutra) in Italia meridionale nel 1985 e nel 2003: recupero della popolazione o efficienza metodologica? In Abstract of Symposium 'Fauna problematica: conservazione e gestione' (eds F.M. Angelici, F. Petrozzi \& A. Galli), p. 78. Agnesotti editore, Montefiascone, Italy.

Mariani, L. \& Inverni, A. (1986) La Lontra in Umbria. In La Lontra in Italia, censimento, distribuzione e problemi di conservazione di una specie minacciata (ed. F. Cassola), pp. 74-76. WWF, Serie Atti e Studi, 5, Rome, Italy.

Mason, C.F. (1995) Habitat quality, water quality and otter distribution. Hystrix, 7, 195-207.

McAuley, L., Pham, B., Tugwell, P. \& Moher, D. (2009) Does the inclusion of grey literature influence estimates of intervention effectiveness reported in meta-analyses? The Lancet, 356, 12281231.

Olmi, M. \& Zapparoli, M. (eds) (1992) L'Ambiente della Tuscia laziale. Aree protette di interesse naturalistico della Provincia di Viterbo. Università degli studio della Tuscia, Union Printing Edizioni, Viterbo, Italy.

PACLO (2006) Piano d'Azione Nazionale per la Conservazione della Lontra. Ministero dell'Ambiente, Rome, Italy. Http://www. minambiente.it [accessed 12 June 2008].

Papi, R. \& Biselli, F. (2007) La fauna. In Guida ai servizi delle aree naturali protette del Lazio, Riserva Naturale Selva del Lamone, pp. 34-45. Regione Lazio, Beta Tipografica srl., Rome, Italy.

Pavan, G. \& Mazzoldi, P. (1983) Banca dati della distribuzione geografica di 22 specie di mammiferi in Italia. Ministero dell'Agricoltura e delle Foreste, Rome, Italy.

Pennacchi, A. (2003) Viaggio per le città del duce. ASEFI, Latina, Italy. 
Pratesi, F., Pratesi, F. \& TAssi, F. (1977) Guida alla Natura del Lazio e Abruzzo. A. Mondadori Editore, Milano, Italy.

Prigioni, C. (2003) Lutra lutra (Linnaeus, 1758). In Fauna d'Italia Mammalia III Carnivora-Artiodactyle (eds L. Boitani, S. Lovari \& A. Vigna Taglianti), pp. 169-178. Calderini-Il Sole 24 ore, Bologna, Italy.

Prigioni, C., Balestrieri, A., Remonti, L., Sgrosso, S., Priore, G., Misin, C. et al. (2005) Distribution and sprainting activity of the otter (Lutra lutra) in the Pollino National Park (southern Italy). Ethology, Ecology, Evolution, 17, 171-180.

Prigioni, C., Balestrieri, A., Remonti, L., Sgrosso, S. \& Priore, G. (2006) How many otters are there in Italy? Hystrix, 17, 29-36.

Prigioni, C., Balestrieri, A. \& Remonti, L. (2007) Espansione dell'areale della Lontra (Lutra lutra) in Italia meridionale. In Abstract of Symposium 'Fauna problematica: conservazione e gestione' (eds F.M. Angelici, F. Petrozzi \& A. Galli), p. 73. Agnesotti editore, Montefiascone, Italy.

Reggiani, G. \& Loy, A. (2006) Sulle tracce della lontra. In Salvati dall'arca (eds M. Fraissinet \& F. Petretti), pp. 83-106. WWF Italia ONG-Onlus. Alberto Perdisa Editore, Ozzano Emilia, Italy.

Reggiani, G., Calò, C.M. \& Riviello, M.C. (1986) La Lontra nell'Alto Lazio. In La Lontra in Italia, censimento, distribuzione e problemi di conservazione di una specie minacciata (ed.

F. Cassola), pp. 77-8o. WWF, Serie Atti e Studi, 5, Rome, Italy.

Regione Lazio (200o) Carta dell'uso del suolo. Assessorato Urbanistica e Casa. Scala 1:25,00o. Regione Lazio, Roma, Italy.

Regione Lazio (2004) Rapporto sullo stato dell'ambiente del Lazio. Regione Lazio, Assessorato all'Ambiente, Dipartimento al Territorio, Agenzia Regionale per la Protezione Ambientale nel Lazio, Rome, Italy.

Reuther, C. (1995) Habitat networking: a new chance for the otter in Europe? Hystrix, 7, 229-238.

Ruiz-Olmo, J., Lafontaine, L., Prigioni, C. \& Lopez-Martin, J.M. (2002) Pollution and its effects on otter populations in southwestern Europe. In Proceedings of the First Otter Toxicology Conference (eds W.H. Conroy, P. Yoxon \& A.C. Gutleb). Journal of the International Otter Survival Fund, 1, 63-82.

Ruiz-Olmo, J., Loy, A., Cianfranci, C., Yoxon, P., Yoxon, G. DE Silva, P.K. et al. (2008) Lutra lutra. In IUCN Red List of Threatened Species v. 2010.4. Http://iucnredlist.org [accessed 18 March 2011].

SCheibler, E. (1939-1957) Starne, Fagiani e Lepri. Vol. I. I nemici. Gli animali nocivi; Vol. II. L'allevamento; Vol. III. La caccia. Olimpia, 1939/1957/1943, Florence, Italy.

Tilman, D., May, R.M., Lehman, C.L. \& Nowak, M.A. (1994) Habitat destruction and the extinction debt. Nature, 371, 65-66.
Tancioni, L. \& Cataudella, S. (2009) Carta ittica della Provincia di Roma. Contributo alla conoscenza delle acque correnti superficiali. Provincia di Roma, Assessorato alle Politiche dell'Agricoltura, Roma, Italy.

Tinelli, A. \& Tinelli, P. (1986) La Lontra nella Tenuta Presidenziale di Castelporziano. In La Lontra in Italia, censimento, distribuzione e problemi di conservazione di una specie minacciata (ed. F. Cassola), pp. 90-91. WWF, Serie Atti e Studi, 5, Rome, Italy.

Ventriglia, U. (1990) Idrogeologia della provincia di Roma. Amministrazione Provinciale di Roma, Assessorato Lavori Pubblici, Viabilità e Trasporti. Abete Grafica, Rome, Italy.

WAyre, P. (1976) Attuale situazione della Lontra in Italia e proposte per la sua conservazione. Contributi scientifici alla conoscenza del Parco Nazionale d'Abruzzo, Rome, 13, 30-36.

\section{Appendix}

The appendix for this article is available online at http:// journals.cambridge.org

\section{Biographical sketches}

Corrado BAtTisti studies animal communities, particularly of birds and small mammals, and has particular interests in habitat fragmentation, regional ecological network planning and threat analysis. Giovanni Amori studies the ecology, evolution and conservation of small mammals at both European and global scales, and is also involved in studies of species richness, species-area relationships, and prey-predator relationships between rodents, shrews and their predators. FrANCESCO M. ANGELICI is working on carnivores, lagomorphs and ungulates. His interests range from systematics to ecology, management and conservation, and he is currently involved in several projects in West Africa, including on otters. LUCA LUiselLi works on the ecology and conservation of tropical vertebrates, especially snakes and tortoises but also mammals, and is studying prey-predator relationships between small mammals and snakes. Marzio ZapPAROLI is interested in zoocoenoses of anthropogenic habitats, particularly urban environments in Italy. He also studies soil arthropod assemblages of terrestrial ecosystems and agroecosystems of the Mediterranean basin, and the systematics, ecology and biogeography of centipedes. 